http://aps.journals.ac.za

\title{
Trends in Contraceptive Use in Kenya, 1989-1998: The Role of Socio-Economic, Cultural and Family Planning Factors
}

\author{
Murungaru Kimani \\ Senior Lecturer \\ Population Studies and Research Institute (PSRI) \\ University of Nairobi, P. O. Box 30197, Nairobi, Kenya \\ e-mail: murungaruk@uonbi.ac.ke
}

\begin{abstract}
This paper uses the 1989 and 1998 KDHS data sets to examine the role of socioeconomic, cultural and family planning factors in explaining the observed increase in contraceptive use in Kenya during the 1989-1998 period. The key finding of the study is that the increase in the use of modern methods of contraception during this period was not due to the socio-economic changes or the improved family planning environment which occurred during the period, but was rather due to the increased use of contraceptives among those who approved family planning and those who had not experienced an infant/child death. The main conclusion drawn from these findings is that studies focusing on explaining the trends in contraceptive use should take into account the changing patterns of association between the various factors on one hand and contraceptive use on the other.
\end{abstract}

Keywords/terms: family planning, contraceptive use, infant/child death, demographic transition, logistic regression, interactive term 


\section{Introduction}

Fertility in Kenya has continued to decline since the country entered the fertility transition in the 1980s. With total fertility rate of 6.7 births per woman in 1989, Kenyan fertility declined to 5.4 and 4.7 births per woman in 1993 and 1998 respectively (NCPD, 1994; NCPD, 1999). Results from the 1999 census further confirm these reductions in fertility, with a TFR of 5.0 (CBS, 2002). However, the results of the 2003 KDHS suggest that the pace of fertility decline in Kenya may have slowed down. According to the results of this survey, TFR was estimated at 4.9 births per woman while contraceptive use remained unchanged at the 1998 level of 39 percent among married women (CBS, 2004).

Fertility decline in Kenya is considered to have occurred primarily as a result of increased fertility control (NCPD, 1993; Njogu and Martin, 1991). Between 1989 and 1998 the use of contraception increased from 27 percent to 39 percent among married women. Thus, analysing the factors contributing to these trends would enhance our understanding of the dynamics of fertility transition in Kenya.

The literature on demographic transition suggests three possible explanations for the observed increase in contraceptive use in Kenya. The socio-economic explanation is based on the fact that in the process of development, the number of desired children by couples is reduced because of the perceived increased costs associated with many children and the decline in their benefits (Bongaarts, 1997). McGreevey (1984) observe that the alternatives to children and innovation to farming techniques reduced economic advantage of children in Japan and Sweden during the fertility transition. Bangaarts and Watkins (1996) also argue that development is associated with heterogeneous social networks and channels of communication which are more conducive to acceptance of innovations such as practice of contraception. Although it is difficult to empirically demonstrate that family planning programmes have played a significant role, it is noted that 
these programmes also stress the role of small families (Mahmood and Ringheim, 1997).

The cultural explanation is based on the fact that in most traditional cultures in which use of family planning is considered immoral on religious or cultural grounds, widespread practice of contraception would not be expected. In addition, different cultural settings may influence the spread of information on family planning. Spread of such information is expected to be faster in socially intergraded societies: those with shared values, norms and institutions (Casterline, 2001) and diverse and large networks and distinct language (Basu and Amin, 2000). The third explanation is attributed to family planning programs. Such programmes help to satisfy unmet needs for contraception (Bongaarts and Watkins, 1996). The analysis of the effects of such programmes has shown them to have a substantial reduction in unwanted fertility.

Besides the three explanations above, it has also been argued that the worsening economic conditions that coincided with contraceptive increase in Kenya could also have contributed to fertility decline (Sathar and Casterine. 1998; Martine, 1996). Since, however, this trend (in contraceptive use) has not been maintained between 1998 and 2003 even as economic hardships persisted, this argument appears not supported by the data, at least in the recent Kenyan experience.

Results from previous research that explain the trends in contraceptive use in Kenya show a continued decline in the desired family size, consistent with socioeconomic development and decline in mortality (Njogu, 1991; Brass and Jolly, 1993). The observed increase in contraceptive use can be explained partly by the shift in proportions of women in age groups with potential for greater use and changes in the effects of various factors. Specifically, this increase is attributed to increases in the proportion of women with primary school education and the increased effects of infant and child mortality (Njogu, 1991). This analysis, which 
examined contraceptive change between 1977-78 and 1989, did not include the family planning variables. Thus the included variables only partly explained the changes in contraceptive use during this period. Recent studies (Kimani and K'Oyugi, 2004) suggest that including only socio-economic, cultural and family planning factors may not account for all the differences if the patterns of associations between the various variables changed over time. The objective of this paper, therefore, is to examine the roles of the three explanations above including the changes in their effects in accounting for the observed increase in contraceptive use between 1989 and 1998.

\section{Data and Methods}

The analysis presented in this paper utilized data collected from the 1989 and 1998 KDHS. These data sets were based on nationally representative samples in which women in the reproductive ages, 15-49, were interviewed. Our analysis is based on currently married (in legal unions), non-pregnant fecund women. The analysis is guided by the analytical framework expounded by Kimani and K'Oyugi (2004). In this framework socio-economic and cultural factors are assumed to be the basic factors influencing contraceptive use, through a set of proximate factors. These factors will be referred to as the family planning factors The framework is based on the assumption that there is an interrelationship between socio-economic variables on one hand, and the cultural environment on the other. Socio-economic development can accelerate the breakdown of traditional practices whereas some traditional practices can delay the process socio-economic development.

Socio-economic factors included were the standard of living index, residence and education of the woman and that of the husband. The construction of the standard of living index was based on the type of houses and ownership of household goods such as radio and television. Cultural factors included: age at first marriage, and type of marriages. Early ages at marriage and women 
married in polygamous unions are associated with low status of women and lower use of contraceptive (Gage, 1995; Murty and De Vos, 1984). The family planning factors were desire for additional children, listening to the radio, woman's approval of family planning and husband's approval, discussion on family planning, and knowledge on family planning methods. Desire for children is included in this category because it is expected to be influenced by both socio-economic and cultural conditions. In Kenya listening to the radio is one of the factors which have been found to be associated with contraceptive use (Boulary and Valente, 1999; Kimani and K'Oyugi, 2004) and this is attributed to the family planning messages aired through the radio (Westoff and Rodriquez, 1995).

Several demographic variables which are known to be associated with contraceptive use: age, number of living children, and whether the women had experienced an infant or child death were also included. Region was included since research suggests that it can capture aspects of cultural diversity, differences in socio-economic development or even provision of family planning services (Njogu, 1991). Central and Eastern Provinces are combined and reflect the more developed rural parts of Kenya. Nyanza and Western Provinces are of low socio-economic development and are also culturally conservative. Coast Province is predominantly Muslim. The dependent variable is the use a modern method of family planning.

\section{Analytical Techniques}

Both bivariate and multivariate analyses were conducted. Cross-tabulations were used to assess differences in socio-economic, cultural and family planning factors over the two periods. Differences in the associations of the various factors with contraceptive use during 1989 and 1998 were assessed by fitting two separate regression models for each of the period. The final part of our analysis entailed pooling together the two data sets and fitting five logistic regression 
models to assess the role of the various factors in explaining differences in contraceptive use between 1989 and 1998. Several regression models with interactive terms were tested and the final model included such terms which

significantly accounted for the differences in contraceptive use between the two periods.

\section{Results}

Use of modern methods of family planning among currently married women increased from 21.7 percent in 1989 to 34.8 percent in 1998 as shown in Table 1. The data summarised in this table further reveal that changes in socio-economic, cultural, family planning and demographic characteristics over the 1889-1998 period are consistent with the observed increase in contraceptive use as portrayed in Table 1. For example, the proportion of women with at least one dead child declined from 30.6 percent in 1989 to 26.7 percent in 1998. The number of living children also declined over the same period, with 57 percent and 48 percent having four children and over respectively in the two periods..

The standard of living, as reflected by the standard of living index, increased slightly while the respondents' education and that of the husband increased substantially. For instance, the proportion of respondents with no education was 30 percent in 1989 compared to only 15.1 percent in 1998, whereas that of the spouses was 15.1 percent and 8.6 percent during the respective periods. Because of the sampling design in 1989 which over-sampled urban areas, the 1998 sample has a higher proportion of respondents living in rural areas compared to the 1989 sample (Ezeh and Dodoo, 2001).

The cultural environment also appears to have changed in favour of increased contraceptive use during the period. The proportion of women in monogamous unions increased, and the age at first marriage increased substantially. For instance, the proportion of women marrying after age 20 years increased from 
http://aps.journals.ac.za

26.1 percent in 1989 to 35 percent in 1998, while the proportion of women married in monogamous unions also increased to 84 percent in 1998 from 73 percent in 1989. 
Table 1: Percentage distribution of married women in 1989 and 1998 KDHS surveys.

\begin{tabular}{|c|c|c|}
\hline Variable & 1989 & 1998 \\
\hline \multicolumn{3}{|c|}{ Dependent variable } \\
\hline Using & 21.7 & 34.8 \\
\hline \multicolumn{3}{|c|}{ Independent variables } \\
\hline \multicolumn{3}{|c|}{ Demographic factors } \\
\hline \multicolumn{3}{|c|}{ Age } \\
\hline $15-24$ & 22.6 & 23.8 \\
\hline $25-34$ & 42.3 & 39.0 \\
\hline $35+$ & 35.0 & 37.2 \\
\hline \multicolumn{3}{|l|}{ Living Children } \\
\hline $0-1$ & 15.6 & 18.7 \\
\hline $2-3$ & 27.4 & 33.3 \\
\hline $4+$ & 57.0 & 48.0 \\
\hline \multicolumn{3}{|l|}{ Children dead } \\
\hline None & 69.4 & 73.3 \\
\hline At least one dead & 30.6 & 26.7 \\
\hline \multicolumn{3}{|c|}{ Socio-economic factors } \\
\hline \multicolumn{3}{|c|}{ Residence } \\
\hline Urban & 24.1 & 17.6 \\
\hline Rural & 75.1 & 82.4 \\
\hline \multicolumn{3}{|l|}{ Living standard } \\
\hline High & 3.2 & 5.1 \\
\hline Medium & 64.0 & 65.6 \\
\hline Low & 32.8 & 29.3 \\
\hline \multicolumn{3}{|c|}{ Education of respondent } \\
\hline None & 30.0 & 15.1 \\
\hline Primary & 50.6 & 58.4 \\
\hline Secondary & 19.5 & 26.5 \\
\hline
\end{tabular}


Table 1 - Continued

\begin{tabular}{|c|c|c|}
\hline & 1989 & 1998 \\
\hline \multicolumn{3}{|l|}{ Husband's education } \\
\hline none & 15.1 & 8.6 \\
\hline Primary & 49.6 & 49.7 \\
\hline Sec+ + & 35.3 & 41.7 \\
\hline \multicolumn{3}{|l|}{ Cultural factors } \\
\hline \multicolumn{3}{|l|}{ Age at first marriage } \\
\hline$<15$ & 17.0 & 11.9 \\
\hline $15-17$ & 33.2 & 29.3 \\
\hline $18-19$ & 23.7 & 23.8 \\
\hline $20+$ & 26.1 & 35.0 \\
\hline \multicolumn{3}{|l|}{ Type of marriage } \\
\hline Monogamous & 77.3 & 84.1 \\
\hline Polygamous & 22.7 & 15.9 \\
\hline \multicolumn{3}{|l|}{ FP factors } \\
\hline \multicolumn{3}{|l|}{ Listening to Radio } \\
\hline Doesn't & 30.2 & 39.1 \\
\hline Listens everyday & 69.8 & 60.9 \\
\hline \multicolumn{3}{|l|}{ Desire for additional } \\
\hline children & 49.2 & 44.8 \\
\hline Had desire & 50.8 & 55.2 \\
\hline \multicolumn{3}{|l|}{ No desire } \\
\hline \multicolumn{3}{|l|}{ Husband's approval } \\
\hline Doesn't & 18.3 & 21.8 \\
\hline Approves & 81.7 & 78.2 \\
\hline \multicolumn{3}{|l|}{ Respondent's approval } \\
\hline Doesn't & 9.4 & 8.2 \\
\hline Approves & 90.6 & 91.8 \\
\hline \multicolumn{3}{|l|}{ Knowledge of FP } \\
\hline Knows less than 5 methods & 36.4 & 13.5 \\
\hline Knows at least 5 methods & 63.6 & 86.5 \\
\hline
\end{tabular}




\begin{tabular}{lcc}
\hline Discusses FP & & \multicolumn{2}{c}{28.2} \\
No discussion & 34.3 & 71.8 \\
Discusses & 65.7 & \\
& & \\
Region & 11.0 & 4.8 \\
Nairobi & 29.2 & 25.1 \\
Central/Eastern & 10.5 & 14.8 \\
Coast & 14.8 & 25.5 \\
Rift Valley & 34.5 & 29.8 \\
Nyanza/Western & 3704 & 4054 \\
$\mathrm{~N}$ & 100.0 & 100.0 \\
$\%$ & & \\
\hline
\end{tabular}

The environment for the practice of family planning improved as reflected by changes in desired family size, approval of family planning, discussions on family planning and level of knowledge on family planning methods. The proportion of respondents who desired no additional children in 1998 was 55 percent compared to slightly less than 51 percent in 1989. On the other hand, the proportion of respondents who had knowledge of at least 5 methods of family planning methods was 86.5 percent in 1998 compared to 63.6 percent in 1989. Similarly, the proportion of respondents discussing matters relating to family planning also increased as shown in the table. However, the proportion of respondents who thought that their husbands approved family planning was slightly lower in 1998 (78.2 percent) compared to 1989 (81.7 percent).

\section{Period Effects}

Table 2 gives the coefficients for the logistic regression models for each of the two periods. The results summarized in this table show that the factors significantly associated with contraceptive use were similar over the two periods. The socio-economic factors which were found to be significant at both periods are education of the women and place of residence. The number of living children was also significantly and positively associated with contraceptive use. This appears to imply that women are more likely to use contraception when the desired family size is attained. All the family planning 
factors included - desire for more children, listening to the radio, respondent's and husband's approval, knowledge on family planning, and discussions on family planning - were consistent in their associations with contraceptive use during the two periods. These factors were all positively associated with probabilities of contraceptive use.

Further examination of the results summarised in the Table shows some changes in the patterns of association over the period. The experience of no death was only significantly associated with contraceptive use only in 1998. Women who had not experienced a child death in 1998 were about 1.4 times as likely to use contraception compared to those who had experienced such deaths. The pattern of association between contraceptive use and socio-economic factors such as education and standards of living also changed. Women with primary education and those with secondary and above were 1.5 and 2.6 times respectively as likely to use contraception in 1989 compared with 1.3 and 1.5 times respectively in 1998. This suggests that the effects of women's education on contraceptive use tend to converge. This is consistent with results from other studies in which convergence is observed as contraceptive use ceases to be an innovative behaviour and becomes habitual among all women regardless of educational background (Martin, 1995).

The association between contraceptive use and urbanization slightly changed during the period. Women in urban areas were 1.4 and 1.8 times as likely to use contraception in 1989 and 1998 respectively compared to those in rural areas. The patterns of association between the region and contraceptive use also changed during the period. The use of contraception was significantly lower in Nyanza/Western region compared to the Coast region in 1989. In 1998 on the other hand, contraceptive use in Nyanza/Western region was, however, not statistically significantly different from that of the Coast region, whereas it was significantly higher for central/Eastern compared to the Coast region. The 
patterns of association between contraceptive use and family planning factors remained fairly constant except for the respondent's approval of family planning and discussions on family planning. The impact of the former increased whereas that for the latter was lower in 1998. 
Table 2 Logistic regression coefficients for current use of a modern method of contraception in 1989 and 1998.

\begin{tabular}{llccc}
\hline Variable & $\mathbf{1 9 8 9}$ & \multicolumn{2}{c}{$\mathbf{1 9 9 8}$} \\
\hline $\begin{array}{l}\text { Demographic variables } \\
\text { Age }\end{array}$ & Reg coeff & $\begin{array}{l}\text { Odds } \\
\text { ratio }\end{array}$ & $\begin{array}{l}\text { Reg } \\
\text { coeff }\end{array}$ & $\begin{array}{l}\text { Odds } \\
\text { ratio }\end{array}$ \\
$15-24$ & na & & & \\
$25-34$ & 0.245 & 1.000 & na & 1.000 \\
$35+$ & $0.454^{*}$ & 1.278 & 0.0518 & 1.053 \\
& & 1.561 & 0.2269 & 1.255
\end{tabular}

\section{Living Children}

$0-1$ (ref)

2-3

$4+$

$\begin{array}{llll}\text { na } & 1.000 & \text { na } & 1.000 \\ 0.752^{\text {** }} & 2.121 & 0.4246^{* *} & 1.532 \\ 0.839^{\text {** }} & 2.313 & 0.5301^{\text {** }} & 1.699\end{array}$

\section{Children dead}

At least dead

None

$\begin{array}{llll}\text { na } & 1.000 & \text { na } & 1.000 \\ 0.026 & 1.0262 & 0.310^{*} & 1.364\end{array}$

Socio-economic

Residence

Rural (ref)

Urban

$\begin{array}{llll}\text { na } & 1.000 & \text { na } & 1.000 \\ 0.595^{\text {** }} & 1.813 & 0.3606^{* *} & 1.434\end{array}$

Living standards

Low (ref)

Medium

$\begin{array}{llll}\text { na } & 1.000 & \text { na } & 1.000 \\ 0.241 & 1.272 & 0.179 & 1.196 \\ 0.376 & 1.457 & 0.419^{*} & 1.521\end{array}$

High

1.457

1.521

Respondents' education

None (ref)

Primary

$\begin{array}{llll}\text { na } & 1.000 & \text { na } & 1.000 \\ 0.428^{\text {** }} & 1.533 & 0.280^{*} & 1.323 \\ 0.964^{\text {** }} & 2.621 & 0.434^{* *} & 1.544\end{array}$

Sec+

$0.434^{* *}$

1.544

Husband's education

None (ref)

Primary

na

na

Sec+

$\begin{array}{llll}0.154 & 1.167 & 0.316 & 1.371 \\ 0.344 & 1.411 & 0.686^{\text {** }} & 1.986\end{array}$


Table 2 - continued

\begin{tabular}{|c|c|c|c|c|}
\hline \multicolumn{5}{|l|}{ Cultural } \\
\hline \multicolumn{5}{|l|}{ Type of marriage } \\
\hline Polygamous (ref) & na & 1.000 & na & 1.000 \\
\hline Monogamous & 0.099 & 1.104 & $0.2772^{*}$ & 1.319 \\
\hline \multicolumn{5}{|l|}{ Age at first marriage } \\
\hline$<15$ & na & 1.000 & na & 1.000 \\
\hline $15-17$ & -0.199 & 0.820 & 0.195 & 1.215 \\
\hline $18-19$ & -0.107 & 0.899 & $0.299^{*}$ & 1.348 \\
\hline $20+$ & -0.043 & 0.958 & $0.324^{*}$ & 1.383 \\
\hline \multicolumn{5}{|l|}{ Family planning } \\
\hline Desire for none (ref) & na & 1.000 & na & 1.000 \\
\hline $\begin{array}{l}\text { Desire for more } \\
\text { children }\end{array}$ & $0.711^{* *}$ & 2.036 & $0.627^{\star *}$ & 1.8720 \\
\hline \multicolumn{5}{|l|}{ Listening to radio } \\
\hline Doesn't (ref) & na & & na & \\
\hline Listens daily & $0.336^{*}$ & 1.399 & $0.3007^{\text {** }}$ & 1.351 \\
\hline \multicolumn{5}{|l|}{ Husbands' approval } \\
\hline Doesn't approve (ref) & na & 1.000 & na & 1.000 \\
\hline Approves & $0.7919^{* *+}$ & 2.208 & $0.902^{* *}$ & 2.465 \\
\hline \multicolumn{5}{|l|}{ Respondent's } \\
\hline Doesn't approve(ref) & $0.7776^{\text {*k }}$ & 2.176 & $2.258^{* *}$ & 9.566 \\
\hline \multicolumn{5}{|l|}{ Approves } \\
\hline \multicolumn{5}{|l|}{ Knowledge on FP } \\
\hline Knows less than 5 & na & 1.000 & na & 1.000 \\
\hline methods(ref) & $0.5763^{* *}$ & 1.779 & $0.4858^{\text {** }}$ & 1.626 \\
\hline \multicolumn{5}{|l|}{$\begin{array}{l}\text { Knows } 5 \text { methods or } \\
\text { more }\end{array}$} \\
\hline \multicolumn{5}{|l|}{ Discuss FP } \\
\hline Doesn't (ref) & na & 1.000 & na & 1.000 \\
\hline Discusses & $1.443^{* *}$ & 4.233 & $0.919^{* *}$ & 2.506 \\
\hline \multicolumn{5}{|l|}{ Region } \\
\hline Coast (ref) & na & 1.000 & na & 1.000 \\
\hline Nairobi & -0.158 & 0.854 & 0.258 & 1.295 \\
\hline Central/Eastern & 0.313 & 1.368 & $0.634^{* *}$ & 1.885 \\
\hline Nyanza/Western & $-0.668^{* k}$ & 0.513 & -0.198 & 0.821 \\
\hline Rift Valley & 0.118 & 1.125 & 0.060 & 1.062 \\
\hline Constant & -6.890 & & -7.616 & \\
\hline - 2 log likelihood & 2958.5 & & 4164.5 & \\
\hline$x^{2}$ & 917.1 & & 1074 & \\
\hline $\mathrm{df}$ & 26 & & 26 & \\
\hline Significance & 0.0000 & & 0.0000 & \\
\hline${ }^{*} \mathrm{P}<0.05$ & & & .01 & \\
\hline
\end{tabular}


In order to examine the role of the various factors in explaining the differences in contraceptive use between 1989 and 1998 a multivariate model was fitted by pooling the two data sets together. The results are summarized in Table 3.

The models summarized in this Table reveal that the differences in socioeconomic and family planning factors between the two periods do not explain the differences in contraceptive use between the two periods of time. In Model II in which demographic variables and that for the region are included, differences in contraceptive use between the two periods are observed to widen. This implies that the overall demographic and the regional composition of the 1989 sample was more favourable to the practise of contraception compared with the 1998 sample. However, when the socio-economic factors are included in Model III the differences in contraceptive use between the two periods are only reduced slightly. The inclusion of cultural variables in Model IV further reduces these differences slightly. The differences widened again when the family planning variables are included in Model V, to about 1.9 times in 1998 compared to 1989, which is nearly the level before adjusting for various factors.

Model VI shows that this difference is accounted for by the interactive terms of the woman's approval of family planning, child mortality and discussions with spouse, on one hand, and the period variable on the other. As shown in this Table, when these interactive terms are included in the model, the differences in contraceptive use between the two periods are no longer statistically significant. In fact, it is observed that the use of contraception is now lower in 1998 compared to 1989. An important point to note, however, is the different effects of the interactive terms. Both the coefficients for the interactive terms of child mortality and approval of family planning are positive which implies that they reduce the differences in the contraceptive use between the two periods while that for the discussion is negative and hence has the opposite effect. 
Tableau 3: Logistic regression coefficients explaining period differences in contraceptive use

\begin{tabular}{|c|c|c|c|c|c|c|}
\hline Variable & Model I & $\begin{array}{l}\text { Model } \\
\text { II }\end{array}$ & $\begin{array}{l}\text { Model } \\
\text { III }\end{array}$ & $\begin{array}{l}\text { Model } \\
\text { IV }\end{array}$ & $\begin{array}{l}\text { Model } \\
\text { V }\end{array}$ & $\begin{array}{l}\text { Model } \\
\text { VI }\end{array}$ \\
\hline \multicolumn{7}{|l|}{ Region } \\
\hline 1989 (ref) & na & na & na & na & na & na \\
\hline 1998 & $\begin{array}{l}0.654^{* *} \\
(1.924)\end{array}$ & $\begin{array}{l}0.710^{* *} \\
(2.033)\end{array}$ & $\begin{array}{l}0.831^{* *} \\
(2.296)\end{array}$ & $\begin{array}{l}0.675^{\text {** }} \\
(1.964)\end{array}$ & $\begin{array}{l}0.654^{* *} \\
(1.923)\end{array}$ & $\begin{array}{l}-0.640 \\
(0.527)\end{array}$ \\
\hline \multicolumn{7}{|l|}{ Region } \\
\hline Coast (ref) & na & na & na & na & na & na \\
\hline Nairobi & na & $\begin{array}{l}1.206^{* *} \\
(3.341)\end{array}$ & $\begin{array}{l}1.906^{* *} \\
(6.726)\end{array}$ & $\begin{array}{l}0.337^{*} \\
(1.401)\end{array}$ & $\begin{array}{l}0.122 \\
(1.130)\end{array}$ & $\begin{array}{l}0.105 \\
(1.111)\end{array}$ \\
\hline Central/Eastern & na & $\begin{array}{l}1.225^{\text {th }} \\
(3.404)\end{array}$ & $\begin{array}{l}0.910^{\text {th }} \\
(2.485)\end{array}$ & $\begin{array}{l}0.860^{\text {*t }} \\
(2.364)\end{array}$ & $\begin{array}{l}0.542^{* *} \\
(1.719)\end{array}$ & $\begin{array}{l}0.526^{* *} \\
(1.692)\end{array}$ \\
\hline Nyanza/Western & na & $\begin{array}{l}-0.021 \\
(0.979)\end{array}$ & $\begin{array}{l}-0.155 \\
(.856)\end{array}$ & $\begin{array}{l}-0.236 \\
(0.861)\end{array}$ & $\begin{array}{l}-0.345^{\text {** }} \\
(0.709)\end{array}$ & $\begin{array}{l}-0.350^{\text {*** }} \\
(0.705)\end{array}$ \\
\hline Rift Valley & na & $\begin{array}{l}0.442^{* *} \\
(1.555)\end{array}$ & $\begin{array}{l}0.069^{*+*} \\
(1.072)\end{array}$ & $\begin{array}{l}0.150 \\
(1.161)\end{array}$ & $\begin{array}{l}0.089^{*+*} \\
(1.093)\end{array}$ & $\begin{array}{l}0.080 \\
(1.083)\end{array}$ \\
\hline $\begin{array}{l}\text { Demographic } \\
\text { Age }\end{array}$ & \multicolumn{6}{|c|}{ Demographic } \\
\hline 15-24 (ref) & na & na & na & na & na & na \\
\hline $25-34$ & na & $\begin{array}{l}0.350^{* *} \\
(1.419)\end{array}$ & $\begin{array}{l}0.307 \\
(1.359)\end{array}$ & $\begin{array}{l}0.137 \\
(1.147)\end{array}$ & $\begin{array}{l}0.116 \\
(1.123)\end{array}$ & $\begin{array}{l}0.123 \\
(1.131)\end{array}$ \\
\hline $35+$ & na & $\begin{array}{l}0.309^{* *} \\
(1.362)\end{array}$ & $\begin{array}{l}0.340^{4+k} \\
(1.405)\end{array}$ & $\begin{array}{l}0.315^{* \star} \\
(1.370)\end{array}$ & $\begin{array}{l}0.302^{*+} \\
(1.352)\end{array}$ & $\begin{array}{l}0.303^{*+*} \\
(1.253)\end{array}$ \\
\hline \multicolumn{7}{|l|}{ Living Children } \\
\hline $0-1$ (ref) & na & na & na & na & na & na \\
\hline $2-3$ & na & $\begin{array}{l}0.591^{* *} \\
(1.805)\end{array}$ & $\begin{array}{l}0.732^{* *} \\
(2.079)\end{array}$ & $\begin{array}{l}0.817^{* k} \\
(2.264)\end{array}$ & $\begin{array}{l}0.505^{* *} \\
(1.657)\end{array}$ & $\begin{array}{l}0.508^{* *} \\
(1.661)\end{array}$ \\
\hline $4+$ & na & $\begin{array}{l}0.673^{\text {*t }} \\
(1.960)\end{array}$ & $\begin{array}{l}0.868^{* *} \\
(2.381)\end{array}$ & $\begin{array}{l}1.253^{* *} \\
(3.499)\end{array}$ & $\begin{array}{l}0.600^{4+} \\
(1.822)\end{array}$ & $\begin{array}{l}0.600^{*+4} \\
(1.823)\end{array}$ \\
\hline \multicolumn{7}{|l|}{ Children dead } \\
\hline At least dead & na & na & na & na & na & na \\
\hline None & na & $\begin{array}{l}0.467^{\text {** }} \\
(1.595)\end{array}$ & $\begin{array}{l}0.531^{* *} \\
(1.700)\end{array}$ & $\begin{array}{l}0.212^{* *} \\
(1.236)\end{array}$ & $\begin{array}{l}0.192^{*} \\
(1.211)\end{array}$ & $\begin{array}{l}0.026 \\
(1.028)\end{array}$ \\
\hline \multicolumn{7}{|l|}{$\begin{array}{l}\text { Socio economic } \\
\text { Living standards }\end{array}$} \\
\hline Low (ref) & na & na & na & na & na & na \\
\hline Medium & & & $0.501^{* *}$ & $0.500^{* *}$ & $0.201^{*}$ & $0.202^{*}$ \\
\hline High & $\begin{array}{l}\text { na } \\
\text { na }\end{array}$ & $\begin{array}{l}\text { na } \\
\text { na }\end{array}$ & $\begin{array}{l}(1.650) \\
0.879^{* *} \\
(2.409)\end{array}$ & $\begin{array}{l}(1.648) \\
0.854^{* *} \\
(2.349)\end{array}$ & $\begin{array}{l}(1.223) \\
0.419^{* *} \\
(1.521)\end{array}$ & $\begin{array}{l}(1.224) \\
0.414^{*} \\
(1.512)\end{array}$ \\
\hline
\end{tabular}




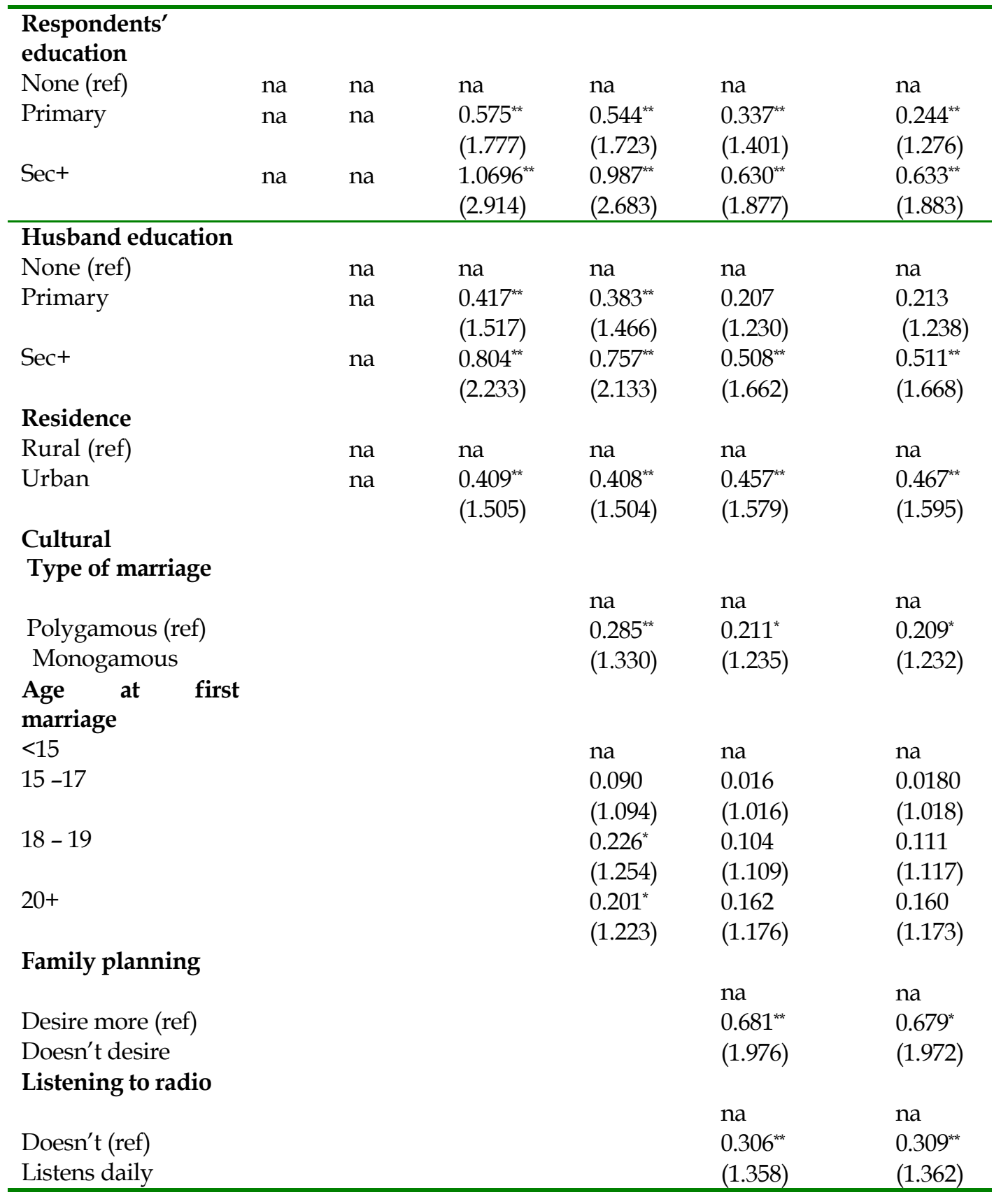


Husbands' approval Doesn't approve

(ref)

Approves

Respondent's

approval

Doesn't approve(ref)

Approves

\section{Knowledge on FP}

Knows less than 5

methods (ref)

Knows 5 or

methods of FP

Discuss FP

None (ref)

Discusses

Approves *Period

Discusses* Period

Child death*Period

Constant

-2 log likelihood

$\mathrm{X}^{2}$

Df

Significance na na

$0.870^{\text {** }} \quad 0.864^{* *}$

(2.387) (2.373)

$\begin{array}{ll}\text { na } & \text { na } \\ 1.758^{* *} & 0.788^{* *} \\ (5.799) & (2.199)\end{array}$

na na

$1.563^{\text {** }} \quad 0.561^{\text {** }}$

(4.772) (1.753)

na na

$1.096^{\text {** }} \quad 1.434^{\text {** }}$

(2.992) (4.196)

$1.536^{* *}$

(4.645)

$-0.506^{\text {*t }}$

(0.603)

$0.289^{*}$

(1.336)

$-6.941$

7154.5

2123.6

30

0.000

Notes: ${ }^{*} \mathrm{P}<0.05{ }^{* *} \mathrm{P}<0.001 \quad$ na=not applicable . Odds ratios in brackets 


\section{Discussion}

The observed increase in contraceptive use between 1989 and 1998 can be largely explained by the changes in the patterns of associations between contraceptive use, on one hand, and infant/child deaths and approval of family planning, on the other, during the two periods. Socio-economic changes during this period, cultural and family planning variables play a relatively minor role. In fact, the inclusion of demographic variables only widened the differences in contraceptive use between the two periods. This suggests that the demographic composition of the 1989 sample was more favourable to contraceptive use. A closer examination of the results presented earlier shows that this was due to reduced effects of age and number of living children which outweighed the increased effects of infant/child mortality which had the opposite effect.

Although inclusion of socio-economic variables reduced the differences (Model III), this was only adequate to outweigh the increased differences arising from the controlling of demographic variables (Model II). Thus our analysis including only socio-economic and demographic variables is consistent with the results from previous studies that these factors alone cannot wholly explain changes in contraceptive use. With the inclusion of family planning variables (Model V), the differences widens due to effects in opposite directions. A closer examination at the results reveals that this is due to the changes in the patterns of association between various factors. Controlling for the respondent's approval of family planning reduced the effects whereas controlling for the discussion had the opposite effect. Thus, the model including socio-economic, cultural and family planning variables does not explain the observed increase in the use of modern methods of contraception. The issue that we must address is: what could account for this increase between the two periods? 
A clue to this will be found by referring to the results of the preliminary analysis of the two logistic regression models one for each of the periods as presented in Table 2. This analysis suggested that the inclusion of interactive terms between contraceptive use and some variables could account for such differences. Testing with several models, this study has demonstrated that these differences could be accounted for by the interactive terms of women's approval, child mortality and discussions on family planning, on one hand, and the period, on the other. When these interaction terms were included in the final model, the differences in contraceptive use between the two periods (as reflected by the period variable) was no longer statistically significant. The interactive term between the period and the variable indicating the experience of an infant/child death show that women who did not have an experience of child death were significantly more likely to use contraceptives in 1998 compared to 1989. This probably suggests that women who had not experienced an infant/child death had increasingly become confident that their children would survive, and were, therefore, more receptive to contraception. It also suggests that, consistent with replacement hypothesis, perceptions about infant and child deaths may have been an inhibiting factor to contraceptive use in Kenya during the earlier period.

The results for the increased effects of respondent's approval probably suggest a more conducive environment for the practice of family planning arising from the reduction in the social costs for contraception. The reduced role of discussion probably also suggests the diminished role of nucleation in families as the practice of contraception becomes increasingly accepted.

One of the key outcomes of the analysis undertaken in this paper is that increased practise of family planning among those who approved family planning and those who had not experienced any infant/child death over the period were the main factors responsible for the continuing demographic transition in Kenya. It seems that socio-economic development has increasingly 
created a favourable environment for the acceptance and practice of family planning in Kenya. The family planning programme, on the other hand, played a key role in changing people's attitudes towards family planning, increasing their knowledge and promoting discussions on family planning.

The other key outcome of this study is the role of the changes in patterns of association between contraceptive use and respondent's approval of family planning and infant/child mortality and its impact on contraceptive use between 1989 and 1998. The implication of this is that even in situations where there has been no change in the levels of approval of family planning or infant/child mortality, increases (or decrease) in contraceptive use can occur if there has been a change in the patterns of effects. As shown in the analysis undertaken in this study, changes in the effects of approval of family planning and infant mortality over time explained the observed increase in contraceptive use between 1989 and 1998 after the roles of socio-economic and family planning factors were taken into account.

Another important observation is that although socio-economic, cultural and family planning factors do not explain the differences in contraceptive use during the period, the approach adopted in our analysis enables us to clarify why this is the case. For example the failure of family planning variables to explain the change was due to the effects in opposing direction of the woman's approval of family planning and discussions. This further implies that even when a set of factors appear not to contribute to explaining an observed change as a group, a full understanding requires analysis of the different roles of various variables within the group which may be acting in opposite direction as in this case. Studies focusing on explaining differences in contraceptive use should, therefore, identify factors whose effects are likely to have changed and ensure the inclusion of interactive terms. 


\section{References}

Basu A. M. and Sejeda Amin. 2000. "Conditioning factors for fertility decline in Bengal: History of language, identity and openness to innovations." Population and Development Review 26(4): 761-794.

Boulay, M. and Thomas W. Valente. 1999. "Social affiliation, interpersonal discussions and family planning knowledge, attitudes and practice." International Family Planning Perspectives 25(3): 112-118.

Bongaarts, J. 1997. "Trends in unwanted childbearing in developing world." Studies in Family Planning 28(4): 267-277.

Bongaarts J. and S. C. Watkins. 1996. "Social interactions and contemporary fertility transitions." Population and Development Review 22(4): 639-682.

Brass, W. and Carole L. Jolly (eds.). 1993. Population Dynamics of Kenya. National Academy Press.

Casterine, J.B. 2001. “The pace of fertility transition: National patterns in the Second Half of the Twentieth Century. In Global Fertility Transition (eds) Rodolfo A. Bulatao and John B. Casterline". Population and Development Review, A supplement to Vol. 27.

Central Bureau of Statistics, Ministry of Planning and National Development. 2002. Kenya Population and Housing Census, Analytical Report on Population Dynamics.

Central Bureau of Statistics (CBS) [Kenya], Ministry of Health (MOH) [Kenya]and ORC Macro. 2004. Kenya Demographic and Health Survey, 2003. Calverton, MD: CBS and ORC Macro.

Ezeh, A. C. and F. N. A. Dodoo. 2001. "Institutional change and the African fertility transition: The case of Kenya." Genus LVII:135-164.

Gage, A.J. 1995. "Women's socio-economic position and contraceptive behaviour in Togo." Studies in Family Planning 26(5): 264-277.

Kimani, M. and B.O. K'Oyugi. 2004. "Regional variations in contraceptive use in Kenya." Genus LX,2: 33-53.

Mahmood, N. and K. Ringheim. 1997. "Knowledge, approval and communication about family planning as correlates of desired fertility among spouses in Pakistan." International Family Planning Perspectives 23(3): 122-129.

Martin, J. C. 1995. “Women's education and fertility: Results from 26 Demographic and Health Surveys." Studies in Family Planning 26(4): 187-202.

Martine, G. 1996. "Brazil's fertility decline, 1965-1995." Population and Development Review 22(1): 47-75.

McGreevey, W. P. 1984. “Economic Aspects of Historical Demographic Change.” World Bank Working Papers No. 685. Population and Development Series. World Bank, Washington DC.

Murty, R. S. and De Vos. 1984. "Ethnic differences in contraceptive use in Sri Lanka." Studies in Family Planning 15(5): 222-232.

National Council for Population and Development (NCPD) [Kenya], Central Bureau of Statistics (CBS) and Macro International Inc. (MI). 1994. Kenya Demographic and Health Survey, 1993. Calverton, MD: NCPD, CBS and MI. CBS and MI.

1999. Kenya Demographic and Health Survey, 1998. Calverton, MD: NCPD,

Njogu, W. 1991. "Trends and determinants of contraceptive use in Kenya." Demography 28(1): 83-99. 
Njogu, W. and Teresa C. Martin. 1991. "Fertility decline in Kenya: The role of timing and spacing of births." In the Proceedings of the Demographic and Health Surveys. World Population Conference IRD/Macro Incorporated Vol. 3 1883-1899.

Sathar, Z. A. and John B. Casterline. 1998. "The onset of fertility transition in Pakistan." Population and Development Review 24(4): 773-796.

Westoff, C. F. and G. Rodriquez. 1995. "The mass media and family planning in Kenya." International Family Planning Perspectives 21(2): 26-31. 